"This is an Author's Original Manuscript of an article whose final and definitive form, the Version of Record, has been published in The Journal of Legislative Studies (22 Feb 2010) [copyright Taylor \& Francis], available online at:

http://www.tandfonline.com/ [DOI :10.1080/13572330903542191]." 


\title{
IDEOLOGICAL CONGRUENCE AMONG EUROPEAN POLITICAL PARTIES ${ }^{1}$
}

\author{
Ana Maria Belchior
}

\begin{abstract}
Do European political parties represent the ideology of their voters well? This research aims to provide an empirical appreciation of the levels to which MPs ideologically represent their electorates within political parties in twelve European countries. The variable used is left-right self-placement and representation is measured through congruence. Three main hypotheses are tested. First, MPs express greater ideological extremism than voters. Second, MPs have biased perceptions on the positioning of their electorates. Third, New Left parties exhibit higher levels of representation than the other parties. Our findings reveal that only the second hypothesis can be supported without restrictions.
\end{abstract}

Keywords: political parties, congruence, left-right, MPs, voters.

Some significant gaps remain in the empirical study of MP-voter representation; this is due largely to data restrictions as these studies usually require an equivalent data base for citizens and parliamentarians. In an attempt to overcome this weakness, we assess representation through measures of MP-voter congruence within political parties. Although the study of representation implies varied levels of analysis ranging from the formation of citizens' preferences to policy outcomes, we disregard the diachronic analysis underlying that process and focus on the synchronic analysis of citizens and their ideological congruence towards the parliamentarians within European political parties. 
Political parties are not only fundamental actors in the democratic process, but also the key official channels that connect the will of the people and its representation in parliaments in Western Europe parliamentary democracies. Furthermore, the link provided by elections serves as a base on which to assess congruence between citizens and elites (Dalton, 1985: 278; Powell, 2000: 5; McDonald \& Budge, 2005). Not only has this role been the focus of little attention to date, but no comparative research has yet been conducted on ideological representation measured through congruence that includes the set of European countries considered here. This is the main purpose of this paper.

We begin with a discussion on representation through congruence. Given the many ways of conceptualizing and operationalizing representation and the implications of its study through congruence, we start by presenting how representation should be considered in this research and how it is measured through congruence. This is followed by the analysis of left-right congruence. The use of this variable raises some comparability problems between MPs and voters that must be duly addressed. The hypotheses and the methodological notes are then presented, after which MP-voter congruence is assessed in each country in order to test if European MPs are ideologically more extreme than their supporters as mainstream research on this subject suggests. In the next section, a study is made of MPs' perceptions of parties' and voters' ideological positioning. Finally, the last section estimates MP-voter congruence within individual European political parties.

\section{Representation through Congruence}

Representation is often said to be a complex concept that goes beyond the assessment of MP-voter congruence. However, congruence can be seen as a valid instrument to assess 
representation albeit limited to measuring the distances between the positions of the representatives and the represented. To this extent, representation occurs if the elected MPs share the ideological positioning and policy preferences of those citizens who voted for them. This straightforward approach of representation provides helpful information about the levels of representatives' responsiveness. We will return to this issue later.

The Responsible Party Model considers political parties to be the core mechanism in the process of democratic representation. On the one hand, it requires voters to judiciously weigh up their vote using information about parties' positions, awarding and punishing incumbent parties based on their performance. On the other hand, the party system is expected to be competitive and political parties are expected to offer distinct policy options, to impose party discipline, and efficiently carry out the mandate given by voters. It is voters' electoral choice that indirectly controls political decisions, given that the political party fulfils the pledges that are supposed to correspond to the will of the voters that elected it. According to this model, voters should vote for the party with views closest to their own and parties should respond to voters' preferences (Converse \& Pierce, 1986: 499-501, 699; Pierce, 1999: 9; Thomassen, 1999: 251-252; Schmitt \& Thomassen, 1999: Chap. 6-9).

Criticisms have been directed at this model both because it must be questioned whether voters give political parties a clear mandate, and also due to the idea that political parties are the exclusive agents of representation (Esaiasson \& Holmberg, 1996: Chap. 15; Thomassen, 1999: 34-35; Dye \& Zeigler, 2006: 180-181, 203-205). Notwithstanding the critics, the model permits our approach to be theoretically supported; indeed, our aim is specifically to centre the analysis on political parties as privileged agents of political representation and assess to what extent they constitute an 
efficient link between voters and leaders ${ }^{2}$. Moreover, there is considerable evidence that the diversity of party alternatives, party cohesion, and the role of parties as a linkage mechanism in the political process in European party systems support the Responsible Party Model (Dalton, 1985: 270-271). We therefore consider the normative assumptions of the model as our theoretical benchmark, that is: assuming that voters tend to behave consistently and that parties perform responsively, we intend to estimate the proximity between parliamentarians and their voters in terms of left-right self-positioning.

Hanna Pitkin advocates that "representing (...) means acting in the interests of the represented, in a manner responsive to them", although she reconciles this with the premise that the representative's action is independent of the represented (Pitkin, 1967: 209, 213, 221-224). This means that representation binds representatives to congruence with the public, though it does not invalidate the case that political decisions may be out of line with the public if the public interest appears to lie elsewhere. From this perspective, congruence is seen as an important characteristic to be encouraged and democratic governments are therefore supposed to reflect the preferences of their citizens (see also: Stimson et al., 1995; Wessels, 1999).

The mandate model of representation, in which the views of electors and their interests determine the political behavior of their representatives, does bring voters closer to the centers of political power even if we admit that it presupposes an agreement that cannot authentically reflect the interests of the represented, or even of democracy; this is important if we consider the increasing sophistication of the electorates in modern democracies. In this sense, the study of MP-voter congruence which goes back to the seminal work of Miller and Stokes (1963) lies at the heart of modern theories of democracy (Huber \& Powell, 1994; Esaiasson \& Holmberg, 1996: 83: Held, 1996: 297334) for some authors. 
It is widely recognized (Pierce, 1999: 25; Thomassen \& Schmitt, 1999a: 19; Thomassen \& Schmitt, 1999b: 186), however, that the empirical implementation of straightforward MP-voter congruence is impossible, and that congruence should not be understood as the legitimate approach to democratic representation (Eulau \& Karps, 1977; Judge, 1990: 20; Thomassen, 1994: 238, 257-258). In contrast to other research (Barnes, 1977), MP-voter congruence is not seen here as a sign of a better or more democratic representation. In fact, congruence should not be seen as a normative good in itself, but as a means of studying democratic representation, and its constraints should be acknowledged (Barnes, 1977: Chap. 8; Eulau \& Karps, 1977). For the purposes of this research, congruence and representation are used as synonyms.

\section{Left-Right Congruence}

A value of the left-right dimension that has been widely validated points to the perception that political parties and individuals are typically located at specific points of a continuum that can be representative of their position on key political issues. Although the little information needed for ideological identification on this continuum allows political actors to be easily placed; it restricts the information on what that positioning means and to what extent it helps define and describe political perspectives (Budge, 2000: 107-108). The linear conception of ideology reduces politics to a singular and elementary dimension, when in fact it is multi-faceted and therefore much more complex.

Many authors have explored the difficulties that may corrupt expectations on the validity of the left-right dimension. For example: Sartori argues that this continuum is, in fact, multidimensional and cannot be reduced to two antagonistic poles (2005 (1976): 116); Inglehart notes that the positioning on the left-right scale can be seen as a simple 
reflection of the ideological stereotype of the party the individual supports (1990: 294); while others defend that only a minority see politics according to an ideological frame namely the better educated and well informed (Converse, 1964; Zaller, 1992). Despite these difficulties, it has been demonstrated that voters can place themselves quite accurately in ideological families and on a left-right scale (Sartori, 2005 (1976): 116; Inglehart \& Klingemann, 1976; Klingemann, 1995: 192). Therefore, despite the limitations, self-positioning on a left-right scale can be seen as a valid variable for ideological positioning. This article strives to measure MP-voter congruence on that scale.

Given that left-right self-positioning is the most relevant structuring dimension in the political debate in most European countries, our research assumes that this variable is a valid measure of ideology. This option is obviously not straightforward. Left-right selfplacement refers to an abstract ideological self-identification, the results of which might differ from those obtained using other variables (e.g. the position towards substantive public policies). Moreover, the comparability of citizens and elites can raise methodological problems. However, the literature suggests that this variable captures the comparative ideological positions of citizens and parliamentarians' reasonably well (Powell, 2000: 162-163; McDonald \& Budge, 2005: 31-38, 228), and it has therefore been used in many studies of mass public and political elites (see e.g. Barnes, 1977; Converse \& Pierce, 1986; Powell, 2000; McDonald \& Budge, 2005).

\section{Findings and Hypotheses}

While some recent studies have reported the existence of a crisis in the representation of electorates (Nadales, 1996), others argue that political parties represent public preferences well (Dalton, 1985: 293-294; Klingemann, 1995: 195). Generally speaking, 
low indices of congruence have been detected between voters and parties (Thomassen, 1994; Miller et al., 1999; Pierce, 1999). The fact is that empirical research has not yet provided any unequivocal answers to MP-voter congruence levels regarding issues or at the institutional level. The degree of congruence seems to vary according to the issue: it is higher for socio-economic or moral issues but lower for external policy matters, and non-existent for topics such as law and order (Thomassen, 1994: 255; Thomassen \& Schmitt, 1999b: 199). But these trends are neither stable nor susceptible to generalization, and may involve other nuances (Dalton, 1985: 380; Thomassen, 1999: 45-52). Nevertheless, at an ideological level, congruence appears to be more significant, particularly with regard to positions on a left-right scale and very ideological matters (Dalton, 1985: 283; Thomassen, 1994: 254-256; Pierce, 1999: 53). At the institutional level, there is also insufficient empirical evidence to clearly assert whether it is proportional versus majority systems, or parliamentary versus presidential systems that produce better levels of congruence (Pierce, 1999; Wlezien \& Soroka, 2007: 809-810). These still remain open ended issues.

Despite the controversy, if we examine specifically left-right congruence at the party level, the mainstream research on this matter has shown that elites on the left and the right are more extreme than their supporters (Dalton, 1985: 275; Converse \& Pierce, 1986: 128; Esaiasson \& Holmberg, 1996: 92-95; Thomassen, 1999: 46-50). Regarding the conditions of the Responsible Party Model, Valen and Narud support that "representatives generally adopt more extreme standpoints than their voters (...) on the "core issues", because "voters do not necessarily wish to vote for parties that reflect their own views (...), but rather prefer the parties that occupy a more extreme position than they do themselves" (2007: 300). The first hypothesis presumes, therefore, that MPs hold a more extreme ideological position than their electorates, especially on the 
left; this is with the exception of the Communist ideological wing where, according to Klingemann (1995: 197-198), greater congruence should be expected.

On the other hand, the dynamics of voters' opinions and attitudes is often constrained by the distorted perception that their parties or candidates share their position, which underestimates the real differences of position between them. Similarly, politicians also tend to erroneously perceive that their voters share their perspective (Esaiasson \& Holmberg, 1996: 116-117; Holmberg, 1999a: 235-251). Hence, greater convergence is expected between MPs' perceptions of the position of their electorates (there is no available data to study voters) and the real position of the electorates. Even greater congruence is expected in relation to their own political parties. This is our second hypothesis.

Finally, the post-materialist explanation attributes strong support to grassroots democracy and to political representation suggesting that the growth of postmaterialism would lead to more democratic political institutions. The Green parties are believed to best match these post-materialist expectations (see for example Inglehart \& Klingemann, 1976; Inglehart, 1990; Müller-Rommel, 1989: 5-19). Although the supposition that green political thought is beyond left and right, the Greens are predominantly identified with the New Left (Inglehart, 1990: 386; Mény \& Knapp, 1998; Poguntke, 2002: 133-144). Thus, the third and final hypothesis predicts that these New Left parties produce higher levels of congruence.

Concomitant with these hypotheses, the levels of congruence produced by individual European political parties are also evaluated. 


\section{Methodological Notes}

The measurement of representation has often rested on an association or correlation between the mean positions of the elite (or parties' political programs) on political matters, and the mean position of their supporters. There are, however, methodological difficulties inherent to this vision mostly related to the different meaning of the mean positioning of MPs and voters in the same scale. As a result, the highest values of association do not necessarily mean greater proximity between the elite and its electorate (see Achen, 1978: 805-815; Eulau, 1987: 171-172; Pierce, 1999: 13-15; Powell, 2000: 94).

On considering these problems, Golder and Stramski warn that the choice for a certain conceptualization of congruence strongly conditions the results (2007). The authors claim that congruence should be seen from one of three structuring perspectives: a oneto-one relationship (between a single citizen and a single representative, or two points that represent a set of citizens and a set of representatives); a many-to-one relationship (between many citizens and a single representative or a point that represents a set of representatives e.g. a political party); and a many-to-many relationship (between many citizens and many representatives). Our analysis of ideological MP-voter congruence best fits the first of those perspectives since we intend to assess congruence between two sets of actors: citizens and representatives.

Like other studies (Huber \& Powell, 1994), mean positions are in general chosen as summary points to represent citizens and representatives. Although the use of mean positions can be problematic, we use a set of measures that allows the mean bias to be controlled. One of the measures to be used considers the median position of citizens instead the mean in order to validate the results and to overcome the bias that the mean might introduce if the distribution is removed from the normal, which is potentially the 
case when it comes to citizens (see e.g. Converse \& Pierce, 1986: 511-516; Holmberg, 1999b: 100-102; Powell, 2000: 94).

Achen devised forms of statistical measurement that cover the different dimensions of congruence, especially: centrism and responsiveness (1978: 483-484, 487-488). These are the two measures to be used complementary to mean analysis. Centrism measures how the representatives actually represent the political preferences of their mean or median voter. It is measured by the difference between the proximity and the variance with regard to the position of the electorate. Proximity relates to the similarity of the party's position to that of its voters. That is:

$$
\hat{S} \mathbf{j}=\sum(a i j-r j)^{2} / n j
$$

where aij is the position of voter $a i$ in party $j, r j$ the mean position of the elite in that party, and $n j$ the size of the sample. And,

$$
\hat{\mathrm{Y}} \mathrm{j}^{2}=\sum(\mathrm{aij}-\overline{\mathrm{a}} \mathrm{j})^{2} /(\mathrm{nj}-1)
$$

measures the variance for the electorate, where $\bar{a} j$ is the median position of the voters; and

$$
\hat{C} j=\hat{S} j-\hat{Y} j^{2}
$$

is the measure of the centrism in party $j$. High centrism values indicate a mismatch between the voters and the elite; low values indicate the reverse. 
As asserted by Golder and Stramski, "by normalizing congruence relative to the dispersion of citizen preferences, relative citizen congruence avoids the use of an abstract left-right scale and provides a metric free concept of congruence" (2007: 1112). The authors note the importance and exceptionality of Achen's proposal to the conceptualization of congruence in relation to the dispersion of citizen preferences. Hence, centrism is considered the most appropriate measure to overcome the potential comparability problems of different perceptions on the left-right scale in different countries.

Responsiveness measures the correspondence between the voters' opinions and those of the elite. This measure consists of a simple linear regression equation as follows:

$$
r=a+b \cdot x i+e,
$$

where $r$ is the expected position of the representatives, $x i$ is the electorate's position, $a$ is the expected position of the representative when the electorate's position is zero, $b$ is the expected change in the representative's position when the electorate's position changes a unit, and $e$ corresponds to the error term. Responsiveness, exists when the opinion of the represented predicts similar opinions in the representatives, i.e. when $b$ equals unity. Responsiveness is also assessed by Pearson's correlation coefficient.

In short, the study of MP-voter congruence is based on the application of three measures: means (and their deviations and differences), centrism, and responsiveness.

The European Representation Studies, hitherto the main European comparative project on political representation, have been a core research source. We use the European Candidates Study (1994) (ECS) and the European Election Study (1994) (EES) from 
this project. The ECS studies candidates for the European Parliament, and the EES is a survey of the European electorates. Both studies are based on representative samples ${ }^{3}$, although the former has some representation problems due to a low response rates ${ }^{4}$. Constraints placed by the variables and parties considered in the studies determined the choice of the ECS for the analysis of the representatives. Therefore, the representatives in our study are, in fact, candidates for the European Parliament and although not elected representatives, this is not an unusual option (Thomassen \& Schmitt, 1999a: 1719). Potential difficulties arising from this choice might be mitigated by the fact that we are dealing with an abstract and structuring issue i.e. left-right position as opposed to substantive policy issues. In this case, party linkage with voters is supposed to be stronger and more perceptible. For simplification purposes, and since party representation is the fundamental aspect, candidates for the European Parliament are designated merely as MPs in this research.

Two other surveys were considered in the case of Portugal in order to include all currently significant parties. One was conducted among Portuguese voters in 2006 as part of the Participation and Democratic Deliberation project promoted by ISCTE (Higher Institute of Social Sciences and Business Studies). The other, carried out by the author in 2007, was aimed at the universe of the Members of Parliament (Assembleia da República) in office in the legislature and is entitled the Study of Portuguese MPs ${ }^{5}$.

The sample is composed of the political parties in European countries for which data was available.

\section{Ideological Congruence of MPs-Voters}

Assessing congruence at the ideological level is considered vital given the structuring role of the left-right dimension for the placement of individuals and parties in the 
political space and the organization of political thought. The first step is to test the first hypothesis of the research: MPs are expected to hold more extreme ideological positions than their electorates, and in particular left wing MPs (the test relating to the Communist wing as the exception can only be carried out later as an individual party analysis is required). A preliminary appreciation of MP-voter congruence based on the spatial distribution of their mean positions on the left-right scale is represented in Figure $1^{6}$.

[FIGURE 1 ABOUT HERE - Left-right self-positioning of MPs and voters within European political parties]

The figure allows us to draw a fundamental conclusion: MPs' positions on the left-right scale appear to be directly and positively related to their voters' positions, with a significant and quite robust statistical linear relationship. The diagonal positioning is only slightly biased at the extremes and more markedly to the left, showing that MPs are relatively further to the left. Although there is clearly an ideological correspondence between MPs and electorates within the European political parties, the relationship does not reflect absolute congruence. For that to be so, the alignment of the spots would have to be more parallel to the diagonal line of the diagram. In short, European political parties seem to be performing a good job in terms of representing voters' ideology; that is, parties satisfactorily correspond to voters' left-right positions.

In order to provide a better understanding of this relationship for each country, Table 1 presents the mean position of its MPs and voters on the left-right scale and the difference between the means. It should be noted that different scales were used for some countries (see notes to the table). 
[TABLE 1 ABOUT HERE - Mean left-right self-positioning of MPs and voters in European political parties]

Data reveals the prevalence of negative differences between the positions of MPs and voters which indicates that the positions assumed by voters at the country level are systematically further to the right than their MPs. Only in Germany does the difference between the means produce a positive sign, but other studies have found that it is not unusual to find German MPs clearly positioned to the left of their voters (Thomassen, 1999: 46). Moreover, German MPs are among the European representatives closest to the mean position of their voters, along with Belgium and the Netherlands (and possibly Sweden, despite its five-point scale). Ireland and Italy have the highest discrepancies towards incongruence among the group of European countries.

The general picture resulting from this analysis supports the expectation that MPs are ideologically more extreme, as well as more to the left than their electors, as demonstrated by several pieces of research on the basis of our hypothesis. These outcomes suggest that the public is not as ideologically committed as the party elite which can be explained in part by the public's low level of political sophistication compared with that of the elite (see e.g. Converse, 1964: 213-214; Converse \& Pierce, 1986: Chap. 7; Dye \& Zeigler, 2006: 3).

As stated above, it is known that objections can be raised about the inferences on representation extracted from the study of mean positions due to its serious limitations. Therefore, in order to confirm our analysis we now apply the two specific measures of representation, as presented in Table 2. 
[Table 2 ABOUT HERE - Measures of representation: left-right self-positioning of MPs and voters in Europe]

Centrism reaffirms that Germany is placed among the European countries whose party system best processes ideological congruence, along with Belgium and the Netherlands. Furthermore, Ireland and Italy still evidence the lowest levels of congruence. On the whole, not only is it impossible to propose a geographical or political pattern for European countries, but we find a prevalence of idiosyncratic and distinct national performances.

Among the measures of correspondence, the regression coefficients show greater ideological polarization of the elite than the voters, since coefficients above unity indicate that voters are ideologically more centrist than MPs. Italy is the exception as higher polarization of voters was found. In all countries, the regression coefficients show that the party systems are not plainly congruent due to the distance between the coefficients and 1 (for the set of European political parties $b=1.33, p<0.001$ ). However, the correlation coefficients indicate that a high degree of correspondence is prevalent within European party systems, since the correlation coefficients are over 0.9 and positive in most countries. As with previous findings, the lowest coefficients relate to Ireland and Italy.

Although party elites appear to be ideologically more extreme than their supporters, each party system generally reflects its electorate internally to a reasonable degree. Therefore, these European party systems seem to be performing their representational function satisfactorily with regard left-right congruence and, consequently, they seem to correspond to the expectations raised by the Responsible Party Model. 


\section{MPs' Perception of Left-Right Congruence}

The importance of political perceptions has been the subject of reflection for many researchers on democratic representation (see for example: Hedlund \& Friesema, 1972; Clausen et al., 1983; Converse \& Pierce, 1986: 221; Thomassen, 1999: 35-36). As the left-right dimension is significant for the positions taken on most political issues, a short incursion into the field of political perceptions is warranted. Data is only available for representatives and is therefore the only perspective analyzed.

In order to assess the second hypothesis, namely that MPs have a biased perception of voters' left-right positions, Figure 2 explores MPs' ideological positions and their perceptions of the positions of their voters and political parties ${ }^{7}$.

[FIGURE 2 ABOUT HERE - Left-right self-positioning of MPs and their perceptions of the positions of their voters and parties]

As expected, remarkable congruence can be observed between MPs' left-right positions and their perception of voters' and political parties' positions in all countries. Perceptual accuracy is usually better on ideology and more politicized issues (Converse \& Pierce, 1986: Chap. 9; Esaiasson \& Holmberg, 1996), so strong congruence is unsurprising. Notwithstanding MPs' recognition of their voters' positioning to their right, in most cases Figure 2 does not reflect the previously reported magnitude of the differences between both actors (see Figure 1 and Table 1). MPs are convinced that they are closer to their supporters than they really are.

A more detailed analysis of MPs' perceptions and voters' positions is displayed in Figure 3. This figure presents the spatial distribution of MPs' mean perception of 
voters' positions on a left-right scale and the real position of voters for all political parties in the sample of countries.

[FIGURE 3 ABOUT HERE - MPs' perceptions and voters' left-right positions]

Despite proving that MPs' perception of the real positions of voters on the left-right divide is not generally far from reality, Figure 3 reveals that MPs are too optimistic about the proximity of voters' positions. Holmberg calls this wishful thinking assimilation ordering model: MPs perceive that their voters' position is closer to their own than it truly is, i.e. "the order of the means reveals an assimilation ordering" which is the most common relationship (1999a: 242-244; see also: Hedlung \& Friesema, 1972: 741). The second hypothesis is thus generally supported, since MPs suppose voters' positioning almost overlaps their own ideological positions, when in fact voters position themselves quite far apart and to the right of MPs.

Despite the conclusion, it is intriguing to note that MPs show a relative sensitivity to their distance from voters when it comes to the political parties with the largest real differences. The relative outliers in Figure 3 generally match with the highest real MPvoter dissimilarities, i.e. the MPs' perceived incongruence is higher in political parties where, correspondingly, there is the greatest MP-voter divergence. For example, the Italian Lega Nord, Forza Italia, and Alleanza Nazionale; the Irish Workers' Party, or even the Belgian PS (Socialist Party) and Ecolo, simultaneously correspond to the parties which exhibit higher MP-voter incongruence and whose MPs perceive that dissimilarity in the direction in which it occurs. The distance from mean positions can be confirmed in Table 3. This finding favors MPs' relative capacity to accurately perceive voters' positions. 
In spite of the relative convergence of MPs' perceptions with the voters' real positions, these findings suggest that from a strictly ideological perspective representatives nearly always assume the existence of a congruence that does not actually exist, and which is far from the truth in some parties. This can have political consequences at the level of the political decision-making process if the feeling that there is a strong ideological correspondence discourages the elite from remaining close to the voters because that they believe they already are. One of the reasons that can be indicated for this discrepancy relates to the heterogeneity of positions recurrently observed among electorates. This seems to be associated with a greater probability of perceptual errors occurring on the part of the elite (Clausen et al., 1983). Since MPs' perception of the electorate's positions seems to be more accurate when it involves highly politicized subjects, greater discrepancies can be expected for less ideological issues. It has been also found that ideological issues do not always produce greater congruence (Thomassen, 1999: 46-51; Belchior, 2007: Chap. 4). Further research on this subject would be welcome in order to clarify this question.

\section{Congruence among European Political Parties}

The presumption that New Left parties' MPs tend to register higher levels of congruence with their supporters is now addressed. The literature has considered ecological parties as closest to the post-materialist prototype and the ones that best represents the New Left party profile. Ecological parties are therefore studied here in contrast with the other political parties.

At the party level, Table 3 presents both the mean position of MPs and voters and their differences for left-right self-positioning and the figures for centrism. Not all the important political parties can be considered in the analysis because unfortunately the 
full data is unavailable for some parties. Only contemporary parties that were included in the studies of both the MPs and citizens were taken into consideration.

The problem of small MP (and occasionally voter) sample volumes occurs with some parties. Although such a limitation is quite common in research of this kind (see e.g. Schmitt \& Thomassen, 1999), it represents a constraint for the interpretation of the results. However, the smallest MP samples generally belong to the smallest parliamentary groups. In addition, the MPs' representational functions make this sample problem less difficult than it would be if we were dealing with ordinary citizens. Moreover, this table to a great extent specifies the analysis thus far conducted. The consistency of its findings with previous results can therefore help to validate the data.

[TABLE 3 ABOUT HERE - Mean left-right self-positioning of MPs and voters and centrism within European political parties]

The conclusions that can be drawn from Table 3 do not clash with those already reached and additional conclusion can also be reached. Firstly, the negative sign accompanying almost all the differences between the means corroborates that MPs persistently position themselves to the left of their voters (including in the ecological parties). The relative exceptions are due to some political parties belonging to the right wing (mainly from nationalist and conservative party families).

Secondly, returning to the first hypothesis of our research and in sharp contrast to the assumption that the Communist wing is expected to be more congruent, we find that not only are Communist parties not amongst the most congruent but also that they belong to the group of the least congruent. Further research is however required on this matter to confirm this hypothesis. 
Thirdly, the ecological parties are also not placed among the most congruent as the differences between the means are generally substantial and centrism is far from zero. Only the Dutch Green Left presents a good MP-voter congruence. Curiously, two ecological parties, namely Les Verts and Ecolo, are among the least congruent parties of all party systems.

In the same vein, Kitschelt noted flaws in the embodiment of the principle of representation among the ecological parties (Kitschelt, 1989: 189, 192-193, 276). In addition, research on representation in Europe reiterates these findings: ecological parties do not seem to display higher levels of ideological congruence than others (Belchior, 2007: Chap. 4). Therefore, from the perspective of ideological congruence, the ecological parties do not appear to uphold the high standards that the theory suggests on the political representation of their supporters. In light of our data, we can conclude that post-materialist predictions on the higher levels of MP-voter correspondence in ecological parties cannot be supported due to a lack of evidence. Consequently, hypothesis 3 is not supported.

\section{Final Remarks}

The Responsible Party Model's idea that parties fully reflect their electorates' ideologies is somewhat unrealistic. In general, the institution of competitive elections has not proved itself to be a sufficiently efficient instrument to maintain the governing elites' responsiveness to the public, especially outside election periods. However, the parties' objectives include the strategic purpose of positioning themselves close to their electorates so as to be successful in elections. Generally speaking and in accordance with that model, our findings reveal that European political parties have a fair performance when it comes to fulfilling their obligations of ideological representation. 
Albeit the relatively strong relationship between left-right positions of voters and representatives, it was also found that European MPs occupy more extreme positions on the left-right divide than their voters, especially on the left. Moreover, MPs have a biased perception of their voters' left-right placement, underestimating the real magnitude of the distances, though not to a great extent in most political parties. Though MPs appear to be ideologically more extreme than their voters and exhibit a relatively biased perception of their voters' positions, internally each party system is generally fairly responsive to their electorates.

Furthermore, if attention is paid to the different meanings that MPs and voters attribute to 'left' and 'right', and to the different levels of their political sophistication, it is never plausible to expect perfect correspondence. MPs' and voters' ideological positions are not conceptually analogous. While the representatives are able to identify their positions, relating them objectively to political ideas, those of voters are generally much less precise. Therefore, discrepancies between the positions of MPs and the public cannot be exclusively interpreted as a weakness in the system of representation. In addition, absolute congruence is not even consensually considered a desirable democratic goal for democratic representation in the strict sense. These findings therefore appear to be satisfactorily optimistic.

The expectations about ecological parties are generally not fulfilled. These research findings do not display enough evidence to validate Inglehart's post-materialist announcement of an alternative and more representative kind of party, anchored in the New Left and especially given form by the ecological parties. Ecological parties do not exhibit better levels of left-right MP-voter congruence than other parties. The weak affiliations and feeble loyalties of these parties as well as their diffuse ideological anchorage may contribute to explaining these results. 
Empirical research on political representation is still under-explored mainly due to data constrictions. We would therefore conclude by suggesting that further research in the field of empirical representation is conducted, especially on issues connected with political cleavages and from a broad comparative perspective. It is also vital that small sample limitations are overcome in future MP-voter comparative analyses. 


\section{References}

Achen, C. (1978) Measuring Representation, American Journal of Political Science, 22(3), pp. 475-510.

Barnes, S. (1977) Representation in Italy (Chicago and London: The University of Chicago Press).

Belchior, A. (2007) Democracia e Representação Partidária [Democracy and Party Representation], PhD Dissertation, IEP - Catholic University of Portugal, Lisbon.

Budge, I. (2000) Expert Judgements of Party Policy Positions, European Journal of Political Research, 37, pp. 103-113.

Clausen, A., Holmberg, S., \& DeHaven-Smith, L. (1983) Contextual Factors in the Accuracy of Leader Perceptions of Constituency Views, The Journal of Politics, 45(2), pp. 449-472.

Converse, P. (1964) The Nature of Belief Systems in Mass Publics, in: D. Apter (ed.) Ideology and Discontent (New York: The Free Press of Glencoe).

Converse, P. \& Pierce, R. (1986) Political Representation in France, (Cambridge and London: The Belknap Press of Harvard University Press).

Dalton, R. (1985) Political Parties and Political Representation, Comparative Political Studies, 18(3), pp. 267-299.

Dye, T. \& Zeigler, H. (2006) The Irony of Democracy, (Belmont: Thomson Wadsworth, 13th ed.).

Esaiasson, P. \& Holmberg, S. (1996) Representation from Above (Aldershot: Dartmouth).

Eulau, H. \& Karps, P. (1977) The Puzzle of Representation, Legislative Studies Quarterly, 2(2), pp.233-254. 
Eulau, H. (1987) The Congruence Model Revisited, Legislative Studies Quarterly, 12(2), pp. 171-214.

Golder, M. \& Stramski, J. (2007) Ideological Congruence and Two Visions of Democracy, paper presented at the 2007 Annual Meeting of the American Political Science Association, Chicago.

Hedlund.R. \& Friesema, P. (1972) Representatives Perceptions of Constituency Opinion, The Journal of Politics, 34(3), pp.730-752.

Held, D. (1996) Models of Democracy (Cambridge: Polity Press).

Holmberg, S. (1999a) Wishful Thinking among European Parliamentarians, in: H. Schmitt and J. Thomassen (eds.) Political Representation and Legitimacy in the European Union (Oxford and New York: Oxford University Press).

Holmberg, S. (1999b) Collective Policy Congruence Compared, in: W. Miller, R. Pierce, J. Thomassen, R. Herrera, S. Holmberg, P. Esaiasson and B. Wessels (orgs.) Policy Representation in Western Democracies (Oxford and New York: Oxford University Press).

Huber, J. \& Powell, Jr., G. (1994) Congruence between Citizens and Policy Makers in Two Visions of Liberal Democracy, World Politics, 46(3), pp.291-326.

Inglehart, R. (1990) Culture Shift in Advanced Industrial Society (Princeton: Princeton University Press).

Inglehart, R. \& Klingemann, H. (1976) Party Identification, Ideological Preference and the Left-Right Dimension among Western Mass Publics, in: I. Budge, I. Crewe and D. Farlie (eds.) Party Identification and Beyond (New York: John Wiley and Sons). Judge, D. (1990) Parliament and Interest Representation, in: M. Rush (ed.) Parliament and Pressure Groups (New York: Oxford University Press). 
Kitschelt, H. (1989) The Logics of Party Formation (New York: Cornell University Press).

Klingemann, H. (1995) Party Positions and Voter Orientations, in: H. Klingemann and D. Fuchs (eds.) Citizens and the State (New York: Oxford University Press).

McDonald, M. \& Budge, I. (2005) Election, Parties, Democracy (Oxford and New York: Oxford University Press).

Mény, Y. \& Knapp, A. (1998) Government and Politics in Western Europe (Oxford: Oxford University Press, 3rd ed.).

Miller, W. \& Stokes, D. (1963) Constituency Influence in Congress, American Science Review, 57(1), pp.45.56.

Miller, W., Pierce, R., Thomassen, J., Herrera, R., Holmberg, S., Esaiasson, P. \& Wessels, B. (1999) Policy Representation in Western Democracies, (Oxford and New York: Oxford University Press).

Müller-Rommel, F. (1989) Green Parties and Alternative Lists under Cross-National Perspective, in: F. Müller-Rommel (ed.) New Politics in Western Europe (Boulder and London: Westview Press).

Nadales, A. (1996) El Debate sobre la Crisis de la Representación Política (Madrid: Editorial Tecnos).

Pierce, R. (1999) Mass-Elite Issue Linkages and the Responsible Party Model Representation, in: W. Miller, R. Pierce, J. Thomassen, R. Herrera, S. Holmberg, P. Esaiasson and B. Wessels (orgs.) Policy Representation in Western Democracies (Oxford and New York: Oxford University Press).

Pitkin, H. (1967) The Concept of Representation (Berkeley: University of California Press). 
Poguntke, T. (2002) Green Parties in National Governments: form Protest to Acquiescence?, in: F. Müller-Rommel and T. Poguntke (eds.) Green Parties in National Governments (London: Frank Cass Publishers).

Powell, Jr., G. (2000) Elections as Instruments of Democracy (New Haven and London: Yale University Press).

Sartori, G. (2005 (1976)) Partidos y Sistemas de Partidos (Madrid: Alianza Editorial).

Schmitt, H. \& Thomassen, J. (eds.) (1999) Political Representation and Legitimacy in the European Union (Oxford and New York: Oxford University Press).

Stimson, J., Mackuen, M., \& R. Erikson (1995) Dynamic Representation, American Political Science Review, 89(3), pp.543-565.

Thomassen, J. (1994) Empirical Research into Political Representation, in: M. Jennings and T. Mann (eds.) Elections at Home and Abroad (Ann Arbor: The University of Michigan Press).

Thomassen, J. (1999) Political Communication between Political Elites and Mass Publics, in: W. Miller, R. Pierce, J. Thomassen, R. Herrera, S. Holmberg, P. Esaiasson and B. Wessels (orgs.) Policy Representation in Western Democracies (Oxford and New York: Oxford University Press).

Thomassen, J. \& Schmitt, H. (1999a) Introduction: Political Representation and Legitimacy in the European Union, in: H. Schmitt and J. Thomassen (eds.) Political Representation and Legitimacy in the European Union (Oxford and New York: Oxford University Press).

Thomassen, J. \& Schmitt, H. (1999b) Issue Congruence, in: H. Schmitt and J. Thomassen (eds.) Political Representation and Legitimacy in the European Union (Oxford and New York: Oxford University Press). 
Thomassen, J. \& Andeweg, R. (2004) Beyond Collective Representation: Individual Members of Parliament and Interest Representation in the Netherlands, The Journal of Legislative Studies, 10(4), pp. 47-69.

Valen H. \& Narud, H. (2007) The Conditional Party Mandate: a Model for the Study of Mass and Elite Opinion Patterns, European Journal of Political Research, 46, pp. 293318.

Wessels, B. (1999) System Characteristics Matter. Empirical Evidence from Ten Representation Studies, in: W. Miller, R. Pierce, J. Thomassen, R. Herrera, S. Holmberg, P. Esaiasson and B. Wessels (orgs.) Policy Representation in Western Democracies (Oxford and New York: Oxford University Press).

Wlezien, C. \& Soroka, S. (2007) The Relationship between Public Opinion and Policy, in: R. Dalton and H. Klingemann (eds.) Oxford Handbook of Political Behavior (Oxford and New York: Oxford University Press).

Zaller, J. (1992) The Nature and Origins of Mass Opinion (Cambridge: Cambridge University Press). 
Figure 1. Left-right self-positioning of MPs and voters within European political parties

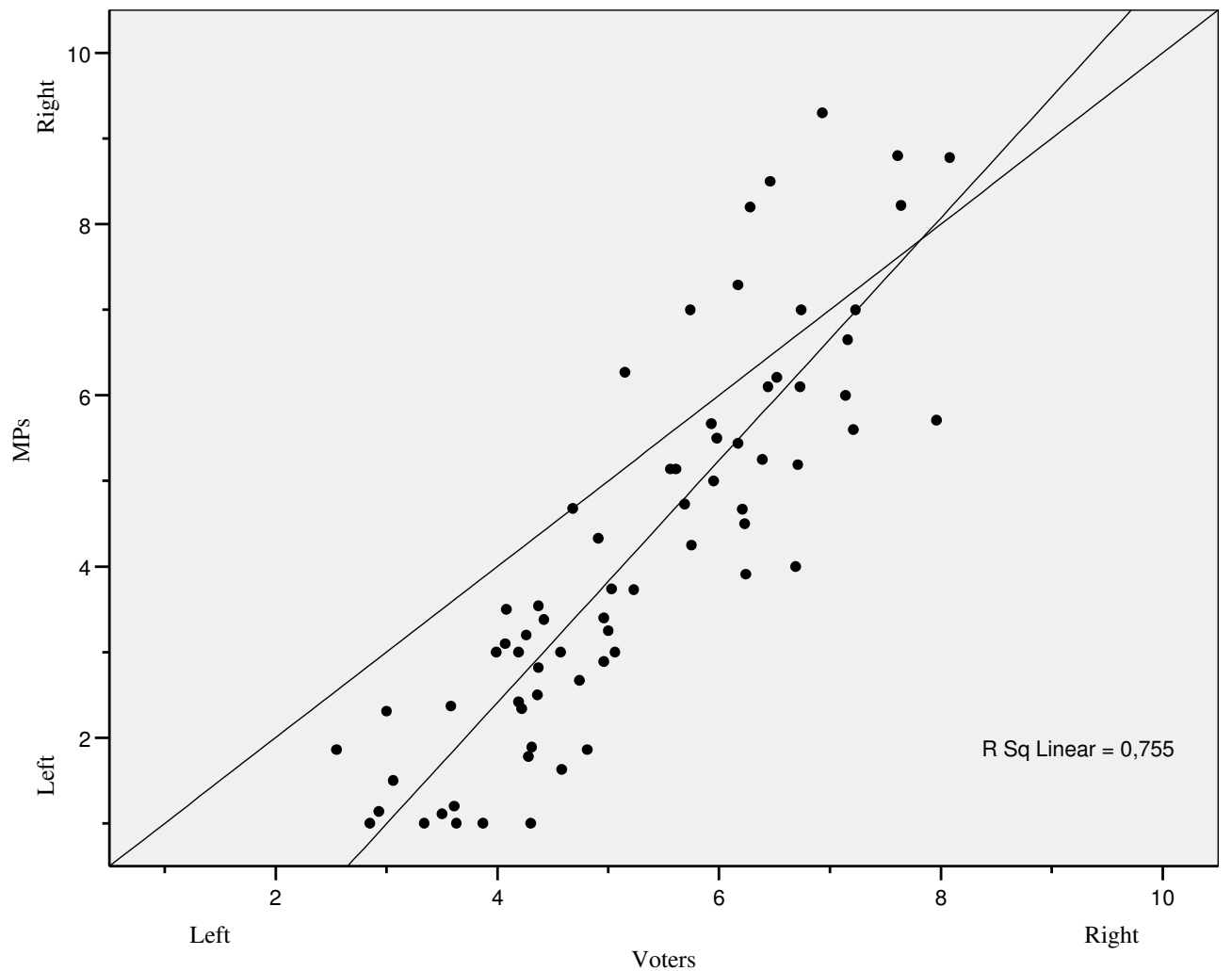

Sources: European Election Study, 1994; European Candidates Study, 1994; Participation and Democratic Deliberation, 2006, and A Study of Portuguese MPs, 2007. 
Table 1. Mean left-right self-positioning of MPs and voters in European political parties

\begin{tabular}{|c|c|c|c|c|c|}
\hline & Year & MPs (a) & Voters (b) & $\begin{array}{l}\text { Difference: } \\
\text { (a) - (b) }\end{array}$ & $\mathbf{N}$ \\
\hline Belgium & 1994 & 4.81 & 5.22 & -0.41 & $\begin{array}{c}\text { MPs } 106 \\
\text { Voters } 2864\end{array}$ \\
\hline Denmark & 1994 & 3.67 & 5.57 & -1.90 & $\begin{array}{c}\text { MPs } 103 \\
\text { Voters } 3331\end{array}$ \\
\hline France & 1994 & 4.30 & 4.95 & -0.65 & $\begin{array}{c}\text { MPs } 94 \\
\text { Voters } 3089\end{array}$ \\
\hline Germany & 1994 & 5.18 & 5.01 & 0.17 & $\begin{array}{c}\text { MPs } 369 \\
\text { Voters } 5969\end{array}$ \\
\hline Ireland & 1994 & 3.40 & 5.67 & -2.27 & $\begin{array}{c}\text { MPs } 10 \\
\text { Voters } 2860\end{array}$ \\
\hline Italy & 1994 & 2.98 & 5.01 & -2.03 & $\begin{array}{c}\text { MPs } 128 \\
\text { Voters } 2979\end{array}$ \\
\hline Luxembourg & 1994 & 3.81 & 5.34 & -1.52 & $\begin{array}{c}\text { MPs } 32 \\
\text { Voters } 1366\end{array}$ \\
\hline Netherlands & 1994 & 4.79 & 5.26 & -0.46 & $\begin{array}{c}\text { MPs } 117 \\
\text { Voters } 3168\end{array}$ \\
\hline Portugal (1) & $2006 / 07$ & 4.27 & 4.90 & -0.63 & $\begin{array}{c}\text { MPs } 79 \\
\text { Voters } 1000\end{array}$ \\
\hline Spain & 1994 & 4.16 & 4.83 & -0.66 & $\begin{array}{c}\text { MPs } 73 \\
\text { Voters } 2765\end{array}$ \\
\hline Sweden (2) & 1988 & 2.69 & 2.93 & -0.24 & $\begin{array}{c}\text { MPs } 339 \\
\text { Voters } 3600\end{array}$ \\
\hline United Kingdom & 1994 & 3.97 & $5 . .27$ & -1.29 & $\begin{array}{c}\text { MPs } 117 \\
\text { Voters } 3187\end{array}$ \\
\hline Europe (3) & 1979 & 4.17 & 5.31 & -1.14 & $\begin{array}{c}\text { MPs } 742 \\
\text { Voters } 8884\end{array}$ \\
\hline
\end{tabular}


Table 2 Measures of representation: left-right self-positioning of MPs and voters in Europe

\begin{tabular}{lccc}
\hline & \multirow{2}{*}{ Centrism } & \multicolumn{2}{c}{ Correspondence $(1)$} \\
\cline { 3 - 4 } Belgium & -0.45 & $2.12^{* * *}$ & $\mathbf{r}$ \\
\hline Denmark & 3.41 & $1.28^{* * *}$ & $0.93^{* * *}$ \\
\hline Germany & -0.96 & $1.54^{* * *}$ & $0.99^{* * *}$ \\
\hline Ireland & 5.06 & $2.15^{*}$ & $0.96^{* * *}$ \\
\hline Italy & 3.17 & $0.51^{* *}$ & $0.84^{*}$ \\
\hline Luxembourg & 1.89 & 1.55 & $0.84^{* *}$ \\
\hline Netherlands & -0.33 & $1.25^{* * *}$ & 0.85 \\
\hline Portugal & 1.72 & $1.44^{*}$ & $0.96^{* * *}$ \\
\hline Spain & -0.94 & 1.37 & $0.91^{*}$ \\
\hline Nas $(1)$ & & 0.92
\end{tabular}

Notes: $(1) * \mathrm{p}<0.05 ; * * \mathrm{p}<0.01 ; * * * \mathrm{p}<0.001$. The sample corresponds to the set of parties for which available data exists in each country. These parties are listed in Table 3 .

Sources: European Election Study, 1994; European Candidates Study, 1994; Participation and Democratic Deliberation, 2006, and Study of Portuguese MPs, 2007. 
Figure 2. Left-right self-positioning of MPs and their perception of the position of their voters and parties

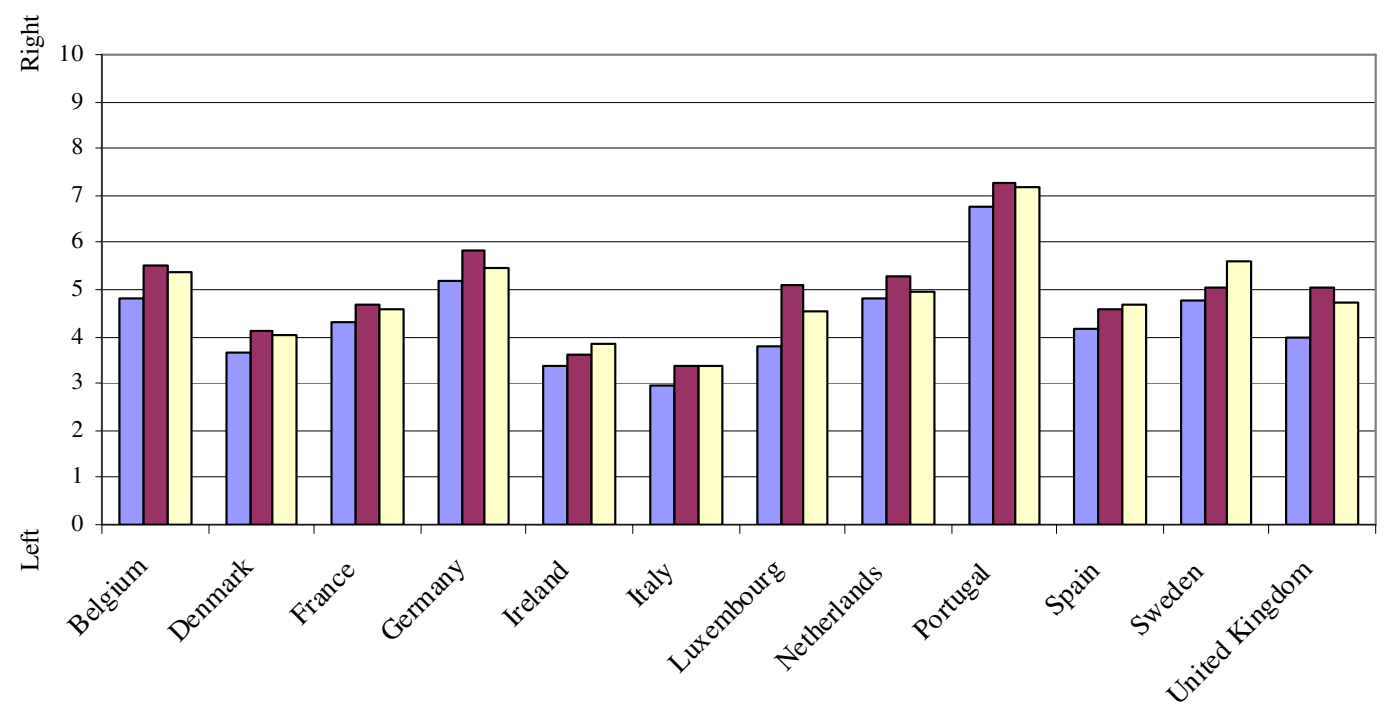

$\square$ MPs' mean position

$\square$ MPs' perception of voters' position

$\square$ MPs' perception of party position

Source: European Candidates Study, 1994. 
Figure 3. MPs' perceptions and voters' left-right positions

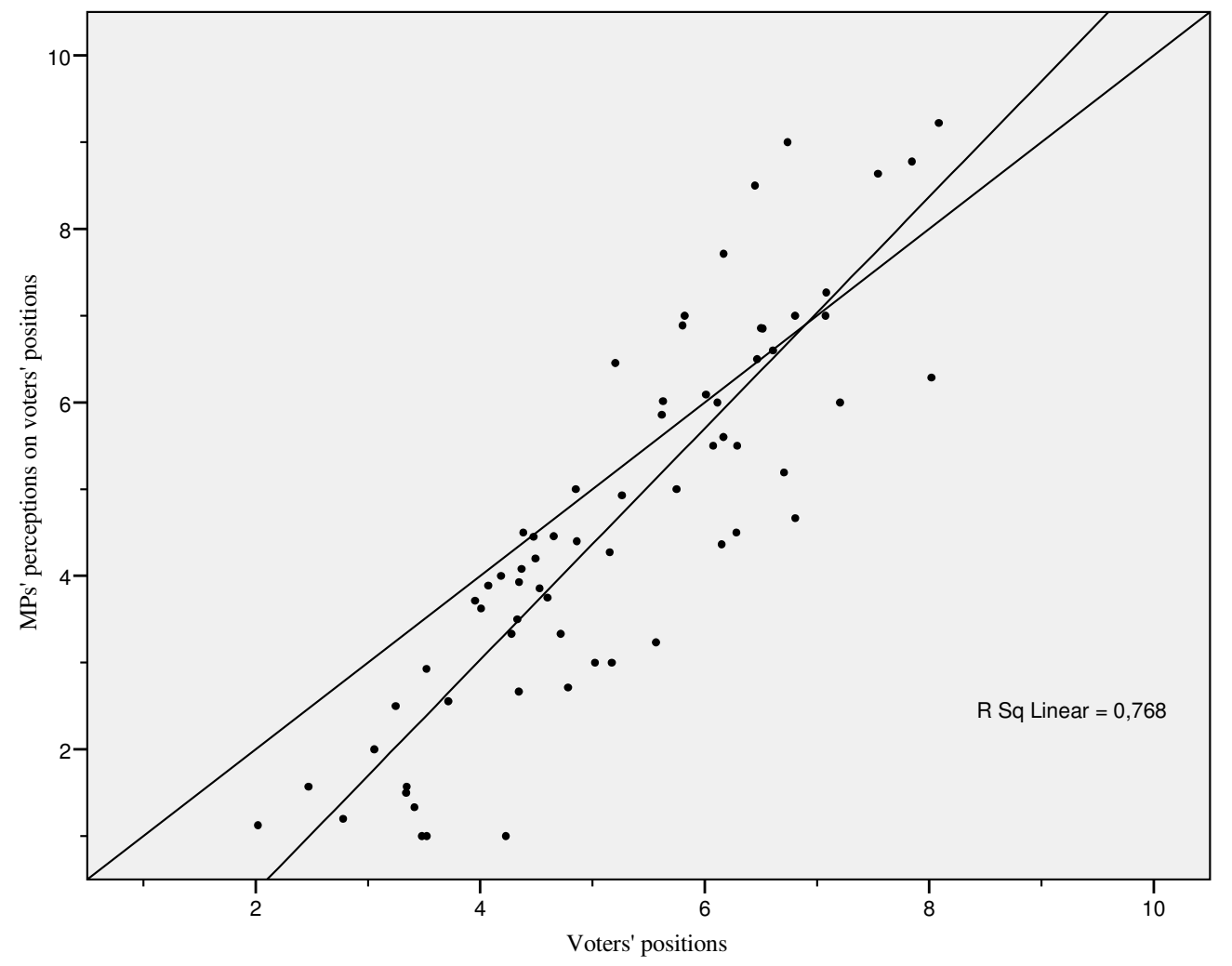

Sources: European Election Study, 1994; European Candidates Study, 1994; Participation and Democratic Deliberation, 2006, and A Study of Portuguese MPs, 2007. 
Table 3. Mean left-right self-positioning of MPs and voters and centrism within European political parties

\begin{tabular}{|c|c|c|c|c|c|c|c|}
\hline & Party & Party family & $\begin{array}{l}\text { MPs } \\
\text { (a) }\end{array}$ & $\begin{array}{l}\text { Voters } \\
\text { (b) }\end{array}$ & $\begin{array}{l}\text { Difference } \\
\text { (a) }- \text { (b) }\end{array}$ & Centrism & $\mathbf{N}$ \\
\hline \multirow{6}{*}{ 忌 } & SPD - Social Democratic Party & $\begin{array}{l}\text { Social- } \\
\text { Democrat }\end{array}$ & 2.82 & 4.37 & -1.55 & 1.93 & $\begin{array}{c}\text { MPs } 66 \\
\text { Voters } 541\end{array}$ \\
\hline & $\begin{array}{l}\text { CDU/CSU - Christian Democratic Union / } \\
\text { Christian Social Union (Bavaria) }\end{array}$ & $\begin{array}{l}\text { Christian- } \\
\text { Democrat }\end{array}$ & 6.21 & 6.52 & -0.31 & -0.95 & $\begin{array}{c}\text { MPs } 71 \\
\text { Voters } 475\end{array}$ \\
\hline & FDP - Free Democratic Party & Liberal & 5.14 & 5.56 & -0.42 & 0.31 & $\begin{array}{c}\text { MPs } 72 \\
\text { Voters } 64\end{array}$ \\
\hline & Die Grünen - The Greens & Ecologist & 3.00 & 3.99 & -0.99 & 0.96 & $\begin{array}{c}\text { MPs } 7 \\
\text { Voters } 274\end{array}$ \\
\hline & NPD - National Democratic Party & Nationalist & 8.22 & 7.64 & 0.58 & 0.30 & $\begin{array}{c}\text { MPs } 9 \\
\text { Voters } 31\end{array}$ \\
\hline & PDS - Party of Democratic Socialism & Communist & 1.14 & 2.93 & -1.79 & 2.21 & $\begin{array}{c}\text { MPs } 8 \\
\text { Voters } 156\end{array}$ \\
\hline \multirow{9}{*}{ 国 } & Agalev - Flemish Greens (Flemish) & Ecologist & 2.50 & 4.36 & -1.86 & 3.44 & $\begin{array}{c}\text { MPs } 12 \\
\text { Voters } 94\end{array}$ \\
\hline & CVP - Christian Democratic Party (Flemish) & $\begin{array}{l}\text { Christian- } \\
\text { Democrat }\end{array}$ & 5.50 & 5.98 & -0.48 & 0.22 & $\begin{array}{c}\text { MPs } 7 \\
\text { Voters } 191\end{array}$ \\
\hline & VLD - Flemish Liberals and Democrats(Flemish) & Liberal & 5.67 & 5.93 & -0.26 & 0.04 & $\begin{array}{c}\text { MPs } 9 \\
\text { Voters } 180\end{array}$ \\
\hline & SP - Socialist Party (Flemish) & $\begin{array}{l}\text { Social- } \\
\text { Democrat }\end{array}$ & 1.78 & 4.28 & -2.5 & 6.22 & $\begin{array}{c}\text { MPs } 11 \\
\text { Voters } 97\end{array}$ \\
\hline & VB - Flemish Block (Flemish) & Special Interest & 9.30 & 6.93 & 2.37 & 4.49 & $\begin{array}{c}\text { MPs } 10 \\
\text { Voters } 26\end{array}$ \\
\hline & VU -People's Union (Flemish) & Special Interest & 4.73 & 5.69 & -0.96 & 0.77 & $\begin{array}{c}\text { MPs } 11 \\
\text { Voters } 20\end{array}$ \\
\hline & PS - Socialist Party (Francophone) & $\begin{array}{c}\text { Social- } \\
\text { Democrat }\end{array}$ & 1.00 & 3.63 & -2.63 & 6.35 & $\begin{array}{c}\text { MPs } 3 \\
\text { Voters } 172\end{array}$ \\
\hline & PSC - Christian Social Party (Francophone) & $\begin{array}{l}\text { Christian- } \\
\text { Democrat }\end{array}$ & 4.67 & 6.21 & -1.54 & 2.31 & $\begin{array}{c}\text { MPs } 10 \\
\text { Voters } 57\end{array}$ \\
\hline & Ecolo - Ecologists (Francophone) & Ecologist & 1.86 & 4.81 & -2.95 & 8.62 & $\begin{array}{c}\text { MPs } 10 \\
\text { Voters } 71\end{array}$ \\
\hline \multirow{5}{*}{ 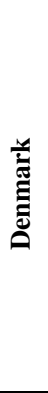 } & SDP - Social Democrats & $\begin{array}{c}\text { Social- } \\
\text { Democrat }\end{array}$ & 2.67 & 4.74 & -2.07 & 4.23 & $\begin{array}{c}\text { MPs } 9 \\
\text { Voters } 418\end{array}$ \\
\hline & KF - Conservative People's Party & Conservative & 6.00 & 7.14 & -1.14 & 1.28 & $\begin{array}{c}\text { MPs } 8 \\
\text { Voters } 179\end{array}$ \\
\hline & SF - Socialist People's Party & $\begin{array}{l}\text { Ecologist / } \\
\text { Social-Democ. }\end{array}$ & 1.11 & 3.50 & -2.39 & 5.44 & $\begin{array}{c}\text { MPs } 10 \\
\text { Voters } 76\end{array}$ \\
\hline & CD - Centre Democrats & $\begin{array}{c}\text { Social- } \\
\text { Democrat }\end{array}$ & 4.25 & 5.75 & -1.5 & 2.13 & $\begin{array}{c}\text { MPs } 12 \\
\text { Voters } 21\end{array}$ \\
\hline & FRP - Progress Party & $\begin{array}{c}\text { Liberal / } \\
\text { Nationalist }\end{array}$ & 5.60 & 7.21 & -1.61 & 2.52 & $\begin{array}{c}\text { MPs } 10 \\
\text { Voters } 46\end{array}$ \\
\hline \multirow{4}{*}{ 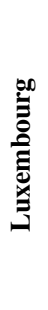 } & PSC CSV - Christian Social People's Party & $\begin{array}{l}\text { Christian- } \\
\text { Democrat }\end{array}$ & 5.25 & 6.39 & -1.14 & 1.14 & $\begin{array}{c}\text { MPs } 4 \\
\text { Voters } 223\end{array}$ \\
\hline & $\begin{array}{l}\text { POSL LSAP - Luxembourg Socialist Workers' } \\
\text { Party }\end{array}$ & $\begin{array}{l}\text { Social- } \\
\text { Democrat }\end{array}$ & 1.63 & 4.58 & -2.95 & 6.19 & $\begin{array}{c}\text { MPs } 9 \\
\text { Voters } 152\end{array}$ \\
\hline & PD DP - Democratic Party & Liberal & 5.14 & 5.61 & -0.47 & -0.17 & $\begin{array}{c}\text { MPs } 7 \\
\text { Voters } 139\end{array}$ \\
\hline & $\begin{array}{l}\text { GAP/GLEI Green List, Ecological Initiative/ Green } \\
\text { Alternative Party }\end{array}$ & Ecologist & 3.38 & 4.42 & -1.04 & 0.75 & $\begin{array}{c}\text { MPs } 8 \\
\text { Voters } 85\end{array}$ \\
\hline \multirow{4}{*}{ 芯 } & PSOE - Spanish Socialist Workers' Party & $\begin{array}{c}\text { Social- } \\
\text { Democrat }\end{array}$ & 2.37 & 3.58 & -1.21 & 1.12 & $\begin{array}{c}\text { MPs } 30 \\
\text { Voters } 273\end{array}$ \\
\hline & PP - People's Party & Conservative & 6.65 & 7.16 & -0.51 & 0.23 & $\begin{array}{c}\text { MPs } 17 \\
\text { Voters } 308\end{array}$ \\
\hline & IU/IC - United Left/Initiative for Catalonia Greens & Communist & 1.00 & 2.85 & -1.85 & 3.41 & $\begin{array}{c}\text { MPs } 5 \\
\text { Voters } 134\end{array}$ \\
\hline & $\mathrm{CDC} / \mathrm{CiU}$ - Convergence and Union & Conservative & 6.27 & 5.15 & 1.12 & 1.19 & $\begin{array}{c}\text { MPs } 12 \\
\text { Voters } 29\end{array}$ \\
\hline
\end{tabular}




\begin{tabular}{|c|c|c|c|c|c|c|c|}
\hline \multirow{3}{*}{ 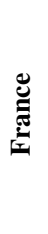 } & $\begin{array}{l}\text { UDF/RPR - Union for French Democracy/Rally for } \\
\text { the Republic }\end{array}$ & Conservative & 7.00 & 6.74 & 0.26 & -0.07 & $\begin{array}{c}\text { MPs } 10 \\
\text { Voters } 252\end{array}$ \\
\hline & FN - National Front & Nationalist & 8.80 & 7.61 & 1.19 & 2.52 & $\begin{array}{c}\text { MPs } 12 \\
\text { Voters } 48\end{array}$ \\
\hline & Les Verts - The Greens & Ecologist & 2.42 & 4.19 & -1.77 & 10.74 & $\begin{array}{c}\text { MPs } 25 \\
\text { Voters } 86\end{array}$ \\
\hline \multirow{5}{*}{ 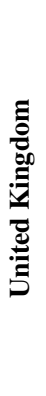 } & Conservative Party & Conservative & 8.50 & 6.46 & 2.04 & 3.93 & $\begin{array}{c}\text { MPs } 18 \\
\text { Voters } 382\end{array}$ \\
\hline & Labour Party & $\begin{array}{c}\text { Social- } \\
\text { Democrat }\end{array}$ & 2.34 & 4.22 & -1.88 & 3.47 & $\begin{array}{c}\text { MPs } 30 \\
\text { Voters } 521\end{array}$ \\
\hline & LDP - Liberal Democratic Party & Liberal & 3.74 & 5.03 & -1.29 & 1.65 & $\begin{array}{c}\text { MPs } 46 \\
\text { Voters } 260\end{array}$ \\
\hline & Greens & Ecologist & 3.10 & 4.07 & -0.97 & 0.78 & $\begin{array}{c}\text { MPs } 32 \\
\text { Voters } 47\end{array}$ \\
\hline & SNP - Scottish National Party (Scottish) & Nationalist & 3.20 & 4.26 & -1.06 & 0.53 & $\begin{array}{c}\text { MPs } 6 \\
\text { Voters } 41\end{array}$ \\
\hline \multirow{7}{*}{ 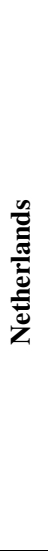 } & CDA - Christian Democratic Appeal & $\begin{array}{l}\text { Christian- } \\
\text { Democrat }\end{array}$ & 5.44 & 6.17 & -0.73 & 0.50 & $\begin{array}{c}\text { MPs } 18 \\
\text { Voters } 374\end{array}$ \\
\hline & PvdA - Labour Party & $\begin{array}{c}\text { Social- } \\
\text { Democrat }\end{array}$ & 3.50 & 4.08 & -0.58 & 0.50 & $\begin{array}{c}\text { MPs } 8 \\
\text { Voters } 329\end{array}$ \\
\hline & VVD - Peoples' Party for Freedom and Democracy & Liberal & 6.10 & 6.44 & -0.34 & -0.20 & $\begin{array}{c}\text { MPs } 23 \\
\text { Voters } 238\end{array}$ \\
\hline & D66 - Democrats 66 & $\begin{array}{c}\text { Social- } \\
\text { Democrat }\end{array}$ & 4.33 & 4.91 & -0.58 & 0.32 & $\begin{array}{c}\text { MPs } 16 \\
\text { Voters } 264\end{array}$ \\
\hline & CD - Centre Democrats & Nationalist & 7.00 & 7.23 & -0.23 & -0.14 & $\begin{array}{c}\text { MPs } 10 \\
\text { Voters } 25\end{array}$ \\
\hline & SP - Socialist Party & $\begin{array}{c}\text { Social- } \\
\text { Democrat }\end{array}$ & 1.20 & 3.61 & -2.41 & 5.32 & $\begin{array}{c}\text { MPs } 11 \\
\text { Voters } 12\end{array}$ \\
\hline & GL - Green Left & Ecologist & 2.31 & 3.00 & -0.69 & 0.46 & $\begin{array}{c}\text { MPs } 16 \\
\text { Voters } 128\end{array}$ \\
\hline \multirow{5}{*}{ 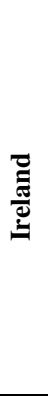 } & FF Fianna Fáil - The Republican Party & Conservative & 4.50 & 6.23 & -1.73 & 2.92 & $\begin{array}{c}\text { MPs } 2 \\
\text { Voters } 577\end{array}$ \\
\hline & Independents & $\begin{array}{c}\text { Social- } \\
\text { Democrat }\end{array}$ & 3.25 & 5.00 & -1.75 & 3.02 & $\begin{array}{c}\text { MPs } 4 \\
\text { Voters } 51\end{array}$ \\
\hline & PD - Progressive Democrats & Liberal & 7.00 & 5.74 & 1.26 & 1.53 & $\begin{array}{c}\text { MPs } 1 \\
\text { Voters } 56\end{array}$ \\
\hline & Greens & Ecologist & 3.00 & 4.57 & -1.57 & 2.24 & $\begin{array}{c}\text { MPs } 3 \\
\text { Voters } 32\end{array}$ \\
\hline & WP - Workers Party of Ireland & Communist & 1.00 & 4.30 & -3.3 & 10.71 & $\begin{array}{c}\text { MPs } 1 \\
\text { Voters } 18\end{array}$ \\
\hline \multirow{4}{*}{$\frac{2}{\pi}$} & LN - Lega Nord & Nationalist & 3.91 & 6.24 & -2.33 & 5.35 & $\begin{array}{c}\text { MPs } 12 \\
\text { Voters } 35\end{array}$ \\
\hline & FI Forza Italia & Conservative & 4.00 & 6.69 & -2.69 & 7.10 & $\begin{array}{c}\text { MPs } 6 \\
\text { Voters } 125\end{array}$ \\
\hline & AN - Alleanza Nazionale & Nationalist & 5.71 & 7.96 & -2.25 & 5.05 & $\begin{array}{c}\text { MPs } 7 \\
\text { Voters } 70\end{array}$ \\
\hline & PPI - Italian People's Party & $\begin{array}{l}\text { Christian- } \\
\text { Democrat }\end{array}$ & 3.73 & 5.23 & -1.5 & 2.19 & $\begin{array}{c}\text { MPs } 11 \\
\text { Voters } 39\end{array}$ \\
\hline \multirow{5}{*}{ 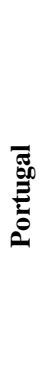 } & BE - Left Block & $\begin{array}{c}\text { Ecologist / } \\
\text { Social-Democ. }\end{array}$ & 1.50 & 3.06 & -1.56 & 2.28 & $\begin{array}{c}\text { MPs } 2 \\
\text { Voters } 40\end{array}$ \\
\hline & CDS/PP - Democratic Social Centre/People's Party & $\begin{array}{l}\text { Christian- } \\
\text { Democrat }\end{array}$ & 7.29 & 6.17 & 1.12 & 0.10 & $\begin{array}{c}\text { MPs } 7 \\
\text { Voters } 12\end{array}$ \\
\hline & CDU - Unitary Democratic Coalition & Communist & 1.00 & 3.34 & -2.34 & 3.84 & $\begin{array}{c}\text { MPs } 4 \\
\text { Voters } 52\end{array}$ \\
\hline & PS - Socialist Party & $\begin{array}{c}\text { Social- } \\
\text { Democrat }\end{array}$ & 3.54 & 4.37 & -0.83 & 0.54 & $\begin{array}{c}\text { MPs } 38 \\
\text { Voters } 272\end{array}$ \\
\hline & PSD - Social Democratic Party & $\begin{array}{c}\text { Social- } \\
\text { Democrat }\end{array}$ & 5.19 & 6.71 & -1.52 & 2.19 & $\begin{array}{c}\text { MPs } 28 \\
\text { Voters } 167\end{array}$ \\
\hline
\end{tabular}
Portuguese MPs, 2007. 
1 The author wishes to thank José M. Leite Viegas and the three anonymous referees for their helpful comments on the earlier drafts of this manuscript.

2 This view is generally supported by the literature; see for example: Thomassen \& Andeweg 2004: 48-49, 61.

3 The EES is based on national multi-stage probability samples and used face-to-face interviews. The universe in each country is the national resident population aged 15 years and older. The ECS was carried out by mail questionnaire addressed to MP candidates to the European Parliament in the 1994 European Parliament election. The overall return rate was 35\%. For more detailed information about these two studies see Schmitt \& Thomassen, 1999: Appendix (these studies are available at the Zentralarchiv für Empirische Sozialforschung - studies ZA3077 and ZA2865).

4 This is not an unusual problem in MP studies, but has important implications in the reading of the data. See for example one of the most important recent works on this subject: Schmitt \& Thomassen, 1999.

5 The Portuguese voters' survey was conducted in July 2006 and comprised a sample of 1001 eligible voters, 18-70 years old. Proportional quota sampling and face-to-face interviews were used. The MPs' survey was carried out in the first three months of 2007 using face-to-face interviews. The response rate corresponds to $34.3 \%$ of the universe. In both studies, question wordings for Portugal are equivalent to these used in the European studies, except for party identification. The question for Portugal is: "Which party did you vote for? (in the last National Parliamentary Elections)".

6 The question, for voters, is: "In political matters people talk of "the left" and "the right". How would you place your views on this scale?" (v114 - EES); and for MPs: "In political manners some people talk about "left" and "right". Where would you place yourself?" (v15_1 - ECS). A ten-point scale is used. The question for the identification of voters' party support is: "Which party would you be most likely to vote for (in 1994 European Elections)" (v16 - EES).

7 The questions are: "In political matters some people talk about "left" and "right". How would you place yourself and others on this scale? Your position? Your party’s voters? Your party's MPs?” (v15 - ECS). A ten-point scale is used. 